\title{
FUNGSI KARINDING \\ BAGI MASYARAKAT CIKALONGKULON KABUPATEN CIANJUR
}

\author{
Oleh Lina Herlinawati \\ Balai Pelestarian Sejarah dan Nilai Tradisional Bandung \\ Jln. Cinambo No. 136 Ujungberung Bandung \\ Email: bpsntbandung@ymail.com
}

\begin{abstract}
Abstrak
Karinding adalah satu jenis alat musik tradisional, dibuat dari bambu atau pelepah enau. Alat musik itu dimainkan oleh mulut disertai pukulan jari tangan, sehingga menghasilkan bunyi yang yang unik dan low decible.

Alat musik tersebut diciptakan oleh leluhur petani Sunda. Selain untuk bermain musik, bunyi alat itu dipercaya dapat mengusir hama dan binatang perusak tanaman. Fungsi karinding demikian itu masih berlangsung pada masyarakat Cikalongkulon Kabupaten Cianjur.

Seiring dengan perkembangan zaman, kemudian karinding menjadi alat hiburan, bahkan kini menjadi bentuk kesenian yang menarik, karena dapat dikolaborasikan dengan alat-alat musik lain.
\end{abstract}

Kata kunci: Karinding, alat musik tradisional.

\section{Abstract}

Karinding is a traditional music instrument, which is made from bamboo or palm leaf. This music instrument is played by mouth, alongside with tap from finger, creating an unique, low decible sound.

This music instrument is created by the Sundanese farmer ancestor. In addition to its function as a music instrument, the sound of this instrument is believed as a pest repellant. This specific function is still believed by the people of Cikalong Kulon in Bandung Residence.

Along with time, karinding developed into an entertainment tool, even as an attractive form of art because its combinable with other music instrument.

Keywords: Karinding, traditional music instrument.

\section{A. Pendahuluan}

Pada kehidupan manusia di mana pun berada, di dalamnya menampung bentuk-bentuk dari ekspresi estetik.
Pemenuhan kebutuhan estetik tersebut, seperti juga pemenuhan sebagian besar pemenuhan kebutuhan lainnya, dilakukan manusia melalui kebudayaannya. Dalam 
pemenuhan kebutuhan estetik ini, kesenian menjadi bagian yang tak terpisahkan dari seluruh kehidupan manusia. Kesenian telah menyertai kehidupan manusia sejak awal-awal kehidupannya. Semua ini menunjukkan keunikan kesenian, baik dilihat dari unsurnya maupun keuniversalannya, sebagai salah satu bagian dari kebudayaan.

Kesenian ada, berkembang, dan dibakukan, di dalam dan melalui tradisi suatu masyarakat. Seperti halnya dengan unsur-unsur kebudayaan lainnya, kesenian juga berfungsi untuk menopang dan mempertahankan kolektivitas sosial. Kesenian adalah milik masyarakat, walaupun dalam kenyataan empirik yang menjadi pendukung kesenian ini adalah individu-individu warga masyarakat yang bersangkutan. Dalam kenyataan empirik, kesenian dapat dilihat sebagai cara hidup yang bertalian dengan keindahan, dari para warga masyarakat.

Kesenian dalam perwujudannya dapat dibagi menjadi tiga kelompok besar, yaitu ekspresi seni yang bersifat visual (seni netra), yaitu yang dicerap pengalaman manusia melalui indera pendengaran; ekspresi seni yang bersifat auditori (seni rungu), yaitu yang dicerap melalui indera pendengaran; dan ekspresi yang bersifat auditori-visual (seni netrarungu), yaitu yang dicerap melalui indera pendengaran dan penglihatan (Rohidi, 2000). Dalam pengertian yang luas, sesungguhnya juga, segala hal ekspresi yang berkaitan dengan keindahan yang bisa dicerap seluruh indera yang dimiliki manusia dapat dan sering digolongkan sebagai seni.

Bentuk atau jenis seni yang dimiliki kelompok-kelompok masyarakat dengan berbagai sifat wujud ekspresi di atas banyak sekali ragamnya. Salah satunya adalah karinding, suatu bentuk kesenian yang dimiliki sekelompok masyarakat pedesaan yang tergolong dalam bentuk ekspresi seni bersifat auditori (seni rungu).

Karinding merupakan alat musik sejenis harpa rahang yang terbuat dari pelepah enau atau bambu. Di Jawa Barat, alat musik ini jika terbuat dari pelepah enau disebut karinding, dan jika terbuat dari bambu disebut karing (Sopandi et al., 1985-1986). Bentuknya kecil, namun bunyinya cukup nyaring. Selain nama alat, karinding juga merupakan nama seni petunjukan yang menggunakan waditra karinding. Alat musik karinding yang berbentuk lempengan kayu enau atau bambu dibentuk sedemikian rupa dengan cara mengiris bagian tengahnya, sehingga terlihat menjulur seperti lidah, yang apabila dipukul akan bergetar dan menimbulkan suara. Untuk memperkeras dan mengatur tinggi rendah bunyi yang dihasilkan, yang diatur adalah rongga mulutnya yang berfungsi sebagai resonator.

Jenis alat musik ini dimiliki oleh berbagai suku bangsa, seperti masyarakat Jawa Tengah, Bali, Lombok, Sumatra, Sumba, Nias, Irian, termasuk masyarakat di tatar Sunda. Karinding pun dapat dikatakan sebagai salah satu seni musik tradisional buhun warisan jaman dulu, yang di beberapa tempat di tatar Sunda masih dapat bertahan, walau harus bertatih-tatih dalam menghadapi perkembangan seni musik populer yang lebih banyak diminati masyarakat.

Masyarakat Cikalongkulon di Kabupaten Cianjur adalah salah satu masyarakat yang masih mengenal alat musik karinding. Para orang tua dulu menggunakan karinding ini sebagai alat untuk mengusir hama di sawah. Sekarang karinding lebih berperan sebagai hiburan, bahkan dalam perkembangannya kemudian mengalami penambahan perangkat, seperti celempung, kacapi. Tak pelak lagi karinding memang unik 
dan bunyi yang dihasilkannya pun enak untuk dinikmati. Bunyi karinding yang futuristik ternyata mampu "berdialog" dengan perangkat musik yang lain.

Perjalanan karinding sebagai seni musik, yang awalnya memiliki fungsi sebagai alat pemelihara dalam pertanian, hingga kemudian menjadi alat hiburan yang unik dan memukau pendengarnya, sangat menarik untuk diungkap. Penulis berkesempatan untuk melakukan penelitian mengenai hal itu. Adapun judul yang penulis ambil adalah "Fungsi Karinding bagi Masyarakat Cikalongkulon di Kabupaten Cianjur".

Tujuan dari penelitian ini adalah untuk memperoleh data dan pengetahuan akan fungsi karinding bagi masyarakat di daerah tersebut di atas, mengingat hingga kini karinding masih lekat dalam kehidupan mereka, yang kemudian menjadi kesenian Karinding yang mendapat tempat di hati para penggemarnya, bahkan di luar wilayahnya. Ruang lingkup materinya sendiri adalah fungsi karinding pada kehidupan sosial budaya masyarakat Desa Cirama Girang yang ada di Kecamatan Cikalongkulon, khususnya dalam berkesenian.

Metode yang digunakan dalam penelitian ini adalah deskriptif analitik. Adapun untuk menjaring data, digunakan teknik observasi dan wawancara dengan menggunakan pedoman wawancara. Sebagai kelengkapan metode wawancara, selain digunakan pedoman wawancara juga alat perekam dan foto kamera.

Selain kedua teknik pengumpulan data di atas, dilakukan pula studi kepustakaan guna menunjang pengetahuan teoritis dan informasi yang berhubungan dengan permasalahan penelitian.

\section{B. Hasil dan Bahasan}

\section{Flora dalam Kehidupan Sosial Budaya Masyarakat Sunda}

Masyarakat Sunda yang terlahir di atas tanah Priangan yang subur dan makmur telah membuktikan dirinya merupakan manusia-manusia yang selalu terkait dan terikat dengan alam lingkungannya. Nandang R. (2003) dalam pengantar tulisannya mengatakan, slogan back to nature adalah slogan yang tidak aneh bagi masyarakat Sunda, karena kebiasaan atau habit yang mereka lakukan sehari-hari adalah suasana alami. Mereka menyatu dengan alam. Alam merupakan bagian yang tak terpisahkan dari kehidupannya.

Keterkaitan dan keterikatan masyarakat Sunda dengan alam lingkungannya telah membentuk pengetahuan, kemampuan, kepercayaan, dan tata nilai, yang dapat dilihat dalam perilaku sehari-harinya, dalam tata cara memperlakukan alam lingkungan sekitarnya.

Flora dan fauna adalah karib setia yang selalu menemani manusia pedesaan dalam kesehariannya hingga kini. Setiap jenis flora yang tumbuh di sekitar lingkungan manusia akan memberi manfaat dan fungsi yang berbeda-beda. Contohnya bambu dan enau.

Bambu, buluh, atau awi (bahasa Sunda) adalah tanaman yang tergolong anak suku bambu - soideae dalam suku Poaceae atau gramineae (rumputrumputan). Tanaman ini berbatang bulat panjang, berongga, berua-ruas, dan berbuku-buku. Bambu mudah ditanam di mana saja dan memiliki ketahanan yang luar biasa. Hal itu terbukti, pada saat Hiroshima luluh lantak akibat bom atom, bambu satu-satunya tanaman yang masih bertahan hidup.

Bambu tumbuh di dataran rendah hingga ketinggian 2.000 dpl., berumpun 
dan beranak pinak. Terdapat banyak jenis bambu, yang masing-masing memiliki nama sendiri. Bentuk, kualitas, dan manfaat dari masing-masing jenis bambu tersebut tidak sama. Di seluruh dunia terdapat sekitar 1.250 jenis bambu dari 75 marga. Di Indonesia sendiri terdapat sekitar 39 jenis bambu dari 8 marga dan lebih dari separuhnya berada di Jawa Barat. Tidak salah, jika kemudian tanaman ini menjadi ikon masyarakat Sunda.

Jenis bambu yang akrab dikenal oleh masyarakat Sunda adalah awi temen, awi bitung, awi gombong, awi tali, awi haur (biasa disebut haur saja), haur koneng, haur gereng, haur cucuk, awi wulung, dan tamiang.

Bambu atau awi memiliki nilai fisik yang sangat berguna, nilai filosofis yang dalam, nilai magis, dan memiliki daya pikat serta ikat sehingga banyak dijadikan lambang/simbol-simbol kehidupan. Bambu memiliki nilai fisik, antara lain: sebagai alat musik tradi-sional, seperti kacapi, suling, taleot, angklung, calung, kohkol, kentongan, karinding, celempung, dan sebagainya; sebagai bahan mainan tradisional Sunda, seperti jajangkungan, gatrik, dan sebagainya; sebagai alat ritual, misalnya selamatan hamil tujuh bulanan, rengkong 'upacara pengambilan padi', elekan bambu tamiang (pada upacara pernikahan), dan sebagainya; sebagai makanan, yaitu iwung 'rebung'; sebagai bahan kertas, seperti bambu duri dan apus; sebagai tanaman hias; sebagai penahan erosi, yaitu dapuran awi 'rumpun bambu'; sebagai peneduh dan peredam suara; sebagai bahan seni; sebagai bahan bangunan rumah; sebagai alat-alat pertanian, seperti kandang, karinjang 'keranjang', rancatan 'pikulan', cireng 'keranjang ikan', karamba, buleng 'tempat ikan dan membawa ikan', oblok 'tempat untuk membawa ikan', dan sebagainya; sebagai alat perang (bambu runcing).

Dalam tulisannya dalam surat kabar Pikiran Rakyat, Retno HY (2008) mengatakan bahwa, musik tradisional yang terbuat dari buluh-buluh bambu merupakan bagian yang tidak terpisahkan dengan kehidupan masyarakat di Jawa Barat (suku Sunda). Kekayaan akan berbagai alat musik tradisional dari bambu yang jumlahnya mencapai 114 jenis, tidak hanya turut memperkaya khazanah musik tanah air, juga alat musik dan kesenian dengan alat musik bambu Jawa Barat turut menjadi menjadi bagian kekayaan musik etnik dunia.

Salah satu permainan alat musik yang ada di pedesaan, yang terbuat dari bambu dan terhitung buhun atau warisan jaman dulu adalah karinding. Karinding pun dapat terbuat dari pelepah pohon enau/aren/kawung.

Enau, aren, atau kawung adalah tanaman yang termasuk dalam suku Arenge Sacchrifera LABILL (pinangpinangan) dalam anak Frenga Pinnata MERR. Pohon berbatang tunggal dan tergolong palem-paleman ini dikenal akrab oleh penduduk pedusunan di daerah pegunungan atau yang berbukitbukit dengan ketinggian $0-1.400 \mathrm{~m} \mathrm{dpl}$. Tempat tumbuh enau dijumpai dari pantai timur India sampai ke Asia Tenggara, termasuk Indonesia. Tinggi pohonnya sampai $15 \mathrm{~m}$ atau lebih. Daunnya majemuk, menyirip dengan anak daun berbentuk pita. Buah berbentuk lonjong, berbiji tiga yang lembek ketika masih muda dan mengeras bila sudah tua. Kulit buah mengandung kristal oksalat, yang menyebabkan rasa gatal bila terkena kulit orang.

Nama enau atau kawung bagi orang Sunda selalu mengingatkan pada hasil-hasil yang bisa diperoleh dan diolah dari pohon ini. Pohon aren/kawung dapat dikatakan pohon yang multiguna, karena 
hampir semua bagian pohonnya dapat dimanfaatkan. Aren terutama berguna sebagai sumber karbohidrat yang diperoleh dari empulur batangnya, yang setelah diolah menghasilkan aci kawung (tepung aren); dan nira yaitu cairan manis hasil penyadapan dari tandan jantannya, dapat diolah menjadi gula aren/kawung, lahang 'minuman segar', bahan untuk membuat cuka atau tuak. Batang lapisan luarnya dipakai untuk talang 'saluran air' dan cukang 'titian' di pedesaan; juga dipakai untuk bahan pembuat dog-dog, semacam gendang yang digunakan pada seni budaya di Jawa Barat. Umbut-nya (pucuk batang yang terdiri atas daundaun yang sangat muda) dimakan sebagai sayur. Ijuknya digunakan sebagai bahan pembuat sikat, tali, keset, bantalan dan atap rumah tradisional. Lunglum atau kawul, yaitu bulu halus pada permukaan dasar pelepah daun, dipakai untuk bahan menyalakan api secara tradisional. Daun tua dipakai untuk pembungkus gula aren dan buah durian. Tulang daunnya dipakai untuk membuat kerajinan anyaman, seperti rigen 'keranjang', dan kerajinan tangan lainnya seperti sapu lidi; jadi harupat, untuk alat penunjuk bagi santri yang belajar mengaji, atau perlengkapan nincak endog dalam ritual upacara pernikahan adat Sunda. Daun mudanya digunakan untuk daun kawung 'kertas rokok tradisional/rokok lintingan'. Dari buah yang muda dapat diperoleh endosperma muda yang dijadikan cangkaleng 'kolang-kaling' untuk minuman, makanan segar, atau kalengan. Dari balukang 'pelepah daun kawung' diambil pakang 'serat'-nya untuk dijadikan tali useup 'tali untuk memancing'.

Petani di Jawa Barat, seperti juga petani di Sumatra Utara, sama-sama enggan menyemaikan biji aren. Ada yang mengatakan tabu, tetapi sesungguhnya karena mereka belum tahu bagaimana mengadakan pembibitan tanaman ini. Pengembangbiakannya masih secara alami, yaitu diserahkan kepada careuh 'musang'. Demikian pula dalam pengolahan hasil-hasilnya masih dilakukan dengan cara tradisional (Ensiklopedi Sunda, 2000). Careuh adalah sejenis binatang seperti kucing, yang salah satu makanan kesukaannya adalah curuluk atau buah aren yang sudah matang. Melalui binatang inilah, benih-benih pohon aren tumbuh di berbagai tempat, baik di hutan maupun di kebun. Usia pohon ini bisa sampai 30 tahun.

Tak hanya sederetan kegunaan di atas, bahkan bagian pelepah pohon ini pun dapat dibuat alat, yang kegunaannya untuk mengusir hama. Perkembangan kemudian, alat ini difungsikan menjadi alat musik tradisional, yang menghasilkan nada-nada suara yang sangat nyaring seperti suara gitar dipetik. Alat tersebut dinamakan karinding.

\section{Karinding dalam Masyarakat Sunda}

Karinding adalah sebuah alat terbuat dari pelepah pohon enau/kawung atau bambu, yang digunakan orang tua Sunda dulu sebagai alat untuk mengusir hama di sawah. Suara yang dihasilkan dari vibrasi jarum karinding adalah suara dengan tingkat decible 'kebisingan' yang rendah atau low decible. Kini, suara dengan tingkat kebisingan seperti itu disebut ultrasonik, yang getarannya hanya bisa didengar oleh serangga, binatang sejenis hama, seperti wereng, simeut 'belalang', jangkrik 'jengkrik', dan sebagainya.

Kini karinding disebut sebagai alat musik karena menghasilkan bunyi. Konon, alat ini sebagai alat yang telah digunakan orang tua dulu (karuhun/leluhur) sejak sebelum ditemukannya kacapi. Usia kacapi sendiri sudah mencapai lebih dari 500 tahun yang lalu. 
Jadi, diperkirakan alat ini sudah lebih tua dari 600 tahun.

Sungguh luar biasa, leluhur kita dapat menciptakan alat pengusir hama sekaligus memberikan keasyikan karena dapat dimainkan sebagai alat musik yang unik dan enak untuk dinikmati. Belakangan kemudian, kita mengetahui dari perkembangan teknologi terkini, microsoft mengeluarkan software anti nyamuk. Demikian pula, TV Media menjual sebuah alat ultrasonic yang disambungkan ke listrik. Yang dihasilkan oleh semua alat-alat tersebut adalah sebuah getaran.

Inilah bedanya ilmu leluhur dengan ilmu kekinian. Ilmu leluhur, alat tidak hanya sekadar alat. Mereka menciptakan alat dengan perhitungan lain yang lebih dari itu. Seperti karinding di atas, sebagai alat pengusir hama, sekaligus bermain musik, bebas pestisida, dan binatang pun harus hidup untuk keseimbangan alam ini. Jadi, binatangnya tidak perlu dibunuh. Kecanggihan alat ini sebagai bukti bahwa karuhun orang Sunda sebagai bangsa yang sudah memiliki kebudayaan, di samping bahasa, tulisan, bahkan hitungannya pun sudah sampai ke tingkat Matrix (tahun 122 Masehi).

Jenis alat seperti karinding ini tidak hanya dimiliki masyarakat suku Sunda saja, juga berbagai suku di daerah, bahkan negara dan bangsa lain. Misalnya, di Jawa Tengah disebut sebagai rinding; di Bali, Lombok, dan Sumatra dikenal sebagai genggong; di Sumba sebagai dungga; di Nias sebagai druri; di Irian sebagai vicon; dan di negera lain alat sejenis dikenal dengan istilah Zeussharp 'harpanya Dewa Zeus'. Bahan yang digunakan untuk membuat karinding, di wilayah Jawa Barat ada dua jenis, yaitu pelepah enau/aren/kawung dan bambu; sedangkan Zeussharp menggunakan bahan besi dan baja.
Dalam masyarakat Sunda, penggunaan jenis bahan dan disain bentuk karinding menunjukkan perbedaan usia, tempat, dan pembeda gender pemakainya. Seperti halnya karinding yang terbuat dari bambu yang lebih menyerupai susuk sanggul 'tusuk sanggul', ini untuk perempuan, karena konon ibu-ibu menyimpannya dengan ditancapkan di sanggul. Adapun yang laki-laki menggunakan pelepah enau/kawung dengan ukuran lebih pendek, karena bisa disimpan di tempat menyimpan bako 'tembakau'. Kemudian perbedaan tempat dimana dibuatnya pun dapat dilihat dari jenis bahan karindingnya. Contohnya, di wilayah Priangan Timur, karinding lebih banyak menggunakan bahan bambu, karena bahan ini menjadi bagian dari kehidupan mereka.

Bentuk karinding berupa lempengan kayu enau/kawung atau bambu yang dibentuk sedemikian rupa dengan cara mengiris bagian tengahnya, sehingga terlihat menjulur seperti lidah, yang apabila dipukul akan bergetar dan menimbulkan suara. Untuk memperkeras dan mengatur tinggi rendahnya bunyi yang dihasilkan, yang diatur adalah rongga mulutnya yang berfungsi sebagai resonator. Besar karinding sebesar pisau lipat, yang terdiri atas tiga ruas, dengan ruas tengahnya terpotong untuk menimbulkan efek getaran. Salah satu sisinya, ada tuas untuk menggetarkan pelepah pipih atau mirip harmonika tapi bentuknya tipis.

Cara memainkan karinding berbeda dengan alat musik jenis mouthharph lainnya, yaitu ditepuk/ dipukul, sedangkan alat lainnya ditoel 'disentuh'. Cara memainkan karinding adalah selain ditiup, ujung karinding dipukul dengan telunjuk sehingga mengeluarkan bunyi. Cara dipukul seperti halnya memperlakukan alat musik perkusi. Ketika 
sudah mampu menghasilkan getaran secara intens, dengan ditempelkan di mulut sebagai resonansinya, dapat memperkeras dan mengatur tinggi rendahnya bunyi yang dihasilkan, serta lidah sebagai pengontrol bunyi yang kita inginkan.

Terdapat beberapa jenis suara yang dihasilkan, yaitu dengan mulut kosong tanpa napas dan dengan menggunakan napas. Dengan dua cara tersebut akan menghasilkan bunyi yang berbeda. Kemudian karinding pun bisa menghasilkan suara yang khas dari tiap orang yang memainkannya. Katakanlah jenis melodi, rhytm, dan bass-nya dapat dihasilkan, atau menurut orang Sunda adalah suara kendang, saron, dan gongnya. Bahkan menyanyikan lagu dengan karinding sekalipun - bukan dengan vokal kita, dapat dilakukan. Hal itu bergantung bagaimana kita bisa memainkan lidah dan napas. Kata orang tua, dulu "menyanyi" bisa dengan menggunakan karinding. Jika sudah terampil dalam memainkan suara karinding, akan ditemukan bagaimana membuat suara untuk berbicara, tetapi suara yang keluar layaknya suara robotik.

Jadi, hal unik dan menarik dari karinding adalah, pertama, dengan cara dipukul ia mampu menghasilkan bunyi yang variatif cukup banyak. Kedua, suara tiap orang yang memainkannya akan berbeda dengan yang lain, walaupun memainkan jenis pukulan (rahel)-nya sama. Hal itu berbeda karena setiap orang memiliki konstruksi mulut yang berbeda. Rahel dalam hal ini adalah ketukan pada waditra karinding.

Karinding yang kemudian berkembang menjadi sebuah kesenian, kesenian Karinding, biasanya dimainkan oleh lima orang, satu di antaranya adalah juru kawih. Empat pemain lainnya memainkan alat musik karinding yang begitu futuristik, dengan suara berbeda.
Bahkan, belakangan karinding dikolaborasikan dengan alat musik kacapi, celempungan, kolotok, dan goong. Kabumi UPI yang dimotori Gianjar Saribanon, bahkan, mengkolaborasikan karinding dengan perkakas musik etnis lainnya. Perangkat musik Amerika Latin, Aborigin, dan Sunda, yaitu lima jimbe, dua digerido, satu kendang, rebab, tarompet, dan rain stick diramu menjadi satu. Kreativitas mereka rupanya hendak membuktikan, bahwa karinding mampu "berdialog" dengan perangkat musik dari berbagai etnis. Hasilnya cukup mengejutkan. Tetabuhan akustik berpadu dengan karinding, menghasilkan nada yang unik, seperti musik dari dunia masa depan.

\section{Sejarah Karinding}

Menurut Oyon Emo Raharjo, warga Citamiang, Desa Pasirmukti, Kecamatan Cineam, Kabupaten Tasikmalaya, karinding memiliki sejarah yang cukup panjang. Karinding merupakan seni turun-temurun yang dimainkan hingga kini oleh warga Citamiang, termasuk dirinya. Diperkirakan seni ini muncul pada pertengahan abad ke-14. Dari cerita rakyat yang beredar secara turun-temurun, pencetus atau pembuat karinding adalah Prabu Kalamanda, putra Raja Galuh Pakuan.

Dikisahkan, pada waktu itu Prabu Kalamanda tertarik pada gadis cantik bernama Sekarwati. Sekarwati adalah putri salah seorang bangsawan di negerinya. Namun, Prabu Kalamanda sangat sulit untuk bertemu dengan gadis ini, karena sang pujaan oleh orang tuanya dipingit. Akhirnya, karena rindu tak tertahankan, Kalamanda membuat alat musik karinding. Karinding pun ia mainkan dekat rumah Sekarwati. Ternyata, bunyi yang dihasilkan dari alat musik tersebut menarik perhatian Sekarwati. Mereka pun bisa bertemu dan 
berkenalan, hingga berujung pada pernikahan.

Ternyata, ada kebiasaan pada jaman dulu. Jika anak muda sudah bisa memainkan kerinding, berarti ia sudah dewasa. Dengan sendirinya, ia bisa apel atau meminang gadis desa yang menjadi pujaannya. Karinding menjadi alat penghubung ungkapan cinta anak muda kala itu.

Walaupun kebiasaan pengungkapan cinta melalui karinding sudah pudar, tidak berarti keseniannya juga ikut tenggelam. Karinding berusaha kembali bangkit, melalui berbagai kesempatan yang ditawarkan berbagai pihak yang terkait dengan masalah kebudayaan, untuk tampil di acara-acara pergelaran kesenian tradisional misalnya.

\section{Fungsi Karinding bagi Masyarakat Cikalongkulon, Kabupaten Cianjur}

\section{a. Sejarah dan Perkembangan Karinding}

Masyarakat Cikalongkulon dalam hal ini masyarakat Desa Cirama Girang - telah lama akrab dengan kesenian Karinding. Desa Cirama Girang sendiri merupakan salah satu dari 18 desa yang ada di Kecamatan Cikalongkulon. Letak desa ini cukup jauh dan berada di wilayah perbukitan dan pegunungan, namun dapat dijangkau dengan menggunakan kendaraan roda dua dan empat. Jalan yang menghubungkan antara desa dan kecamatan sudah beraspal dengan kondisi cukup baik.

Wilayah desa ini tergolong beriklim basah, dengan curah hujan ratarata per tahunnya antara $2.000-3.000$ $\mathrm{mm}$ dan suhu rata-rata hariannya $15^{\circ} \mathrm{C}$. Dalam pemanfaatan lahan yang ada, peruntukan yang menempati posisi terbesar adalah hutan produksi, diikuti tanah perkebunan. Lahan untuk permukiman sendiri terhitung kecil setelah lahan untuk persawahan. Pola perkampungan pada umumnya rumahrumah penduduk mengelompok, beberapa rumah memang ada yang terpisah, menyatu dengan lahan kebun yang dimilikinya.

Sesuai dengan kondisi yang ada di lingkungannya, warga Desa Cirama Girang banyak memanfaatkan sumber daya alam yang ada di sekitarnya, baik sebagai petani sawah, ladang, maupun kebun. Dari data yang ada, warga yang bermatapencaharian sebagai petani menduduki posisi tertinggi, di bawahnya kemudian supir ojeg, pedagang, peternak, buruh swasta, supir, pengrajin, dan PNS.

Dapat dikatakan hampir semua warga Desa Cirama Girang beretnis Sunda dan semuanya memeluk agama Islam. Fasilitas keagamaan yang tersedia ada mesjid jami, mushola/langgar di setiap RT. Untuk kaum ibu, selain ada kegiatan keagamaan dalam wadah majelis taklim, juga ada wadah PKK yang menyalurkan kegiatan yang menunjang kesejahteraan keluarga mereka. Adapun untuk kaum muda, yang terwadahi dalam organisasi Karang Taruna, terdapat kegiatan dalam bidang olah raga dan kesenian. Kesenian yang warga miliki adalah pencak silat, calung, kendang penca, dan karinding.

Keakraban masyarakat dengan karinding telah berlangsung lama, dari dulu, tanpa tahu asal usulnya darimana dan mengapa dinamakan karinding. Yang mereka tahu hanyalah, karinding dulunya adalah alat penghibur diri manakala sedang bekerja di sawah, sekaligus sebagai pengusir hama, seperti yang para orang tua mereka lakukan dulu.

Selanjutnya karinding menjadi alat hiburan bersama dan belakangan menjadi sebuah kesenian, konon berawal dari adanya suatu peristiwa besar, yang kemudian menjadi bahan cerita warga masyarakat dari generasi ke generasi, hingga kisah itu dikenal sebagai sasakala 
bagi mereka. Berikut ini kisah sasakala tersebut:

Pada masa lalu, permainan ngadu hayam 'sabung ayam' menjadi sebuah permainan dan tontonan yang menarik serta banyak diminati masyarakat saat itu. Ketika datang musim ngadu hayam, pemilik ayam-ayam adu akan sibuk mempersiapkan jagoan-jagoannya untuk berlaga di arena adu, melawan para penantangnya.

Demikian, ketika musim ngadu hayam tiba, diadakanlah acara ngadu hayam antarwarga Gunung Congkang melawan warga Gunung Panawungan. Acara tersebut diadakan di wilayah Gunung Panawungan. Ketika salah satu peserta dari kedua daerah tersebut kalah dan tidak menerima, akhirnya berujung terjadi keributan di arena ngadu hayam. Pihak dari Gunung Congkang melempar lawannya dengan biji buah. Sementara itu pihak Gunung Panawungan melempar dengan batu, hingga kemudian di tempat tersebut dikenal dengan sebutan Naringgul, bahkan bekas daerah dekuna 'berlututnya' para pengadu ayam ada dan disebut Ciangiran. Tak disebutkan akhirnya, pihak mana yang "menang". Namun kemudian, untuk mengingat peristiwa itu, setiap hari Jumat Kliwon, masyarakat sering berkumpul sambil memainkan musik karinding sebagai hiburan.

Perkembangan selanjutnya, karinding pun menjadi sebuah bentuk kesenian yang kerap diibingan 'diiringi tarian', bahkan diiringi dengan nyanyian pesinden. Karinding pun dibawakan secara rampak 'bersama-sama' oleh 10 orang dengan bunyi dan kekhasan yang berbeda-beda. Kemudian, baru-baru ini telah terbentuk Grup Karinding yang lengkap serta bisa dikolaborasikan dengan musik Calung. Kesenian Karinding lengkap, dalam artian mendapat tambahan peralatan musik tradisional lain, seperti kacapi, celempung, panambih, dan kecrek.

Kacapi adalah alat petik dalam waditra karawitan Sunda. Bentuknya berdawai dan rurumah kacapi- nya terbuat dari kayu kananga atau mahoni. Kacapi yang digunakan Grup Karinding di Desa Cirama Girang adalah kacapi kawih. Kacapi kawih ini banyak dikembangkan oleh Mang Koko, komponis dengan kekhasannya dalam petikan kacapi, warna suara, dan gaya lagu-lagunya. Kacapi yang dimiliki kelompok karinding ini sangat sederhana, bahkan kayunya terlihat sudah kusam dan tidak licin lagi.

Celempung, waditra tradisional, dibuat dari ruas bambu dengan sembilunya sebagai senar; berfungsi sebagai pengatur irama dalam orkestra yang dinamakan Celempungan. Bahan, seruas bambu (misalnya awi gombong), ukuran diameter lebih kurang $20 \mathrm{~cm}$, panjang lebih kurang $40 \mathrm{~cm}$. Yang dijadikan muka, disulikat 'ditatah diratakan' (membuang sembilu yang tidak dipergunakaan sebagai senar), bagian tengah dilubangi agar suara senar menggema dalam tabung; kedua senar diatur nada-nadanya, yaitu barang galimber (1/da dan 4/ti) atau nada-nada lain yang dikehendaki si pembuat. Kedua senar itu dihubungkan dengan bambu berbentuk persegi panjang $(5 \times 3 \mathrm{~cm})$ disebut sumbi atau lilidah, dipasang tepat pada tengah permukaan atau di atas lubang. Di sampingnya dilubangi lebih kurang $10 \mathrm{~cm}$, untuk mengatur getaran volume udara yang diatur oleh telapak tangan kiri. Di ujung pangkal muka celempung terbentang 2 kerat bambu (5 $X 1 \mathrm{~cm}$ ) untuk alat penegang senar, dinamakan tumpangsari atau inang. Celempung dibunyikan dengan mempergunakan alat pemukul yang disebut tarengteng. 
Panambih. Sebagai panambih, mereka berkreasi menciptakannya sendiri dari 3 tabung paralon dengan ukuran yang berbeda: 2,3 , dan 4 inch. Tabungtabung paralon tersebut ditutup salah satu bagian lubangnya dengan lembaran karet, kemudian diperkuat dengan ikatan. Panambih ini dapat dikatakan sebagai gendangnya. Hal itu tercipta karena keterbatasan, bahkan ketiadaan dana. Sebenarnya, mereka menginginkan panambih itu benar-benar dalam bentuk gendang, kendang.

Mereka berencana ingin menambah perlengkapan kesenian Karinding ini dengan kecrek. Kecreknya terbuat dari bambu, yang salah satu permukaannya disulikat atau diiris memanjang seperti lidah. Jika dipukul-pukul bambunya akan menimbulkan suara.

Kesenian karinding yang lengkap ini telah mampu tampil menghibur warga setempat, baik dalam acara perayaan hari-hari besar maupun kenduri. Untuk tampil di luar wilayahnya, mereka masih ragu karena kelengkapan waditranya yang kelewat sederhana, walaupun dalam kualitas suara musiknya tak terkalahkan dengan waditra yang berpenampilan bagus.

\section{b. Bentuk dan Cara Pembuatan}

Selain dari haur 'bambu', karinding di Desa Cirama Girang pun terbuat dari pelepah pohon enau/kawung. Bentuknya sama seperti umumnya karinding di daerah-derah lain di tatar Sunda, seperti Ciawi, CineamTasikmalaya. Bentuknya kecil dan lebih pendek dibanding karinding yang terbuat dari bahan bambu.

Bahan yang digunakan untuk membuat karinding adalah kawung saeran, yaitu bagian pelepah enau/kawung yang kecil namun sudah tua. Bahan baku seperti itu dianggap baik dan dapat menghasilkan suara yang bagus. Tidak setiap orang mampu memilih bahan baku seperti itu. Hanya orang-orang yang mengenal pohon enau/kawung dengan baik dan mereka yang biasa membuat karinding saja. Namun, setiap orang dapat belajar membuat karinding, yang tentunya tidak dengan sekali belajar saja. Dibutuhkan proses melalui pengalaman beberapa kali pembuatan karinding. Perlengkapan yang dibutuhkan dalam membuat karinding adalah: peso alit/peso raut 'pisau raut', bedog 'golok', silet (untuk melubangi), dan ampelas.

\section{Gambar 1}

Karinding, ciptaan leluhur yang "futuristik".

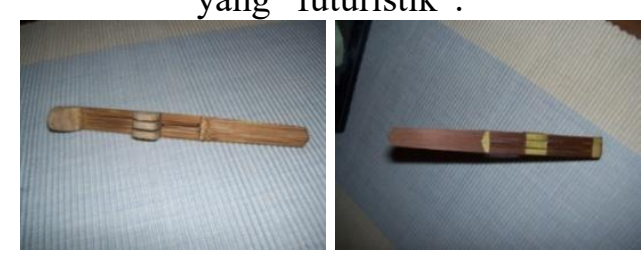

Sumber: Penelitian 2008

Waktu yang dibutuhkan dalam membuat karinding tidak sebentar. Hal itu berkaitan dengan proses pencarian dan pengolahan bahannya sebelum dibentuk, yang membutuhkan beberapa hari. Berdasar pengalaman Bapak Sumardi, seorang seniman karinding sekaligus pembuat karinding, untuk mencari pelepah kawung/aren pilihan dibutuhkan waktu paling tidak sampai 3 hari di pegunungan atau daerah-daerah yang berbukit-bukit, dimana pohon enau/kawung tumbuh.

Setelah ditemukan pohon kawung dengan kawung saeran yang dibutuhkan, bapak Sumardi memanjatnya dengan menggunakan sigay 'sejenis tangga terbuat dari sebatang bambu panjang, yang pada tiap bukunya dilubangi sebagai tempat pijakan jempol kaki ketika memanjat. Pelepah kawung saeran 
pun dipotong dengan golok. Kawung saeran dijemur selama 2 hari hingga kering. Barulah kemudian proses pembuatan dimulai hingga memakan waktu seharian. Jadi, total waktu yang dibutuhkan untuk membuat karinding adalah 6 hari - biasanya menghasilkan 3 buah karinding yang siap pakai.

Untuk mendapatkan karinding yang berbeda-beda bunyinya, maka dibuatnya pun dengan proses yang sedikit berbeda-beda pula. Setelah pelepah kawung kering, kemudian dipotong dan dibentuk sesuai dengan bentuk dasar karinding yang diinginkan. Kembali, bentuk dasar karinding dijemur untuk mendapatkan hasil yang maksimal. Setelah kering, barulah dibelah dan dibentuk karinding, sesuai dengan yang dinginkan. Alat yang digunakan adalah pisau raut, silet, dan ampelas. Dibutuhkan ketelitian dan kesabaran si pembuat, agar bentuk karinding dapat sesuai dengan harapan. Setelah terbentuk karinding, masih harus melalui proses akhir, yaitu dideang 'digarang' dengan diolesi minyak kelapa terlebih dahulu hingga keluar minyaknya. Akhirnya karinding pun siap digunakan.

Alat karinding bagi mereka sebagai pemakai, yang telah akrab dengan keberadaan dan suaranya, seakan sudah menjadi kelengkapan seharian. Alat ini tak pernah lepas dari sakunya, disisipkan di tempat tembakau atau rokok. Untuk memperpanjang usia alat ini, mereka memperhatikan betul caracara memeliharanya. Berikut ini bentukbentuk pemeliharaan karinding, yaitu: menempatkan atau menyimpan karinding di tempat kering agar tidak kaibunan 'lembab' lagi; dan agar suara karinding nyaring kembali, harus dideang atau dijemur kembali secara rutin, serta pada sela-sela belahan karinding digunakan paseuk 'pasak' tipis, agar belahan tidak adek 'menyatu' lagi.

\section{c. Cara Memainkan Karinding}

Cara memainkan karinding di Desa Cirama Girang sama saja dengan di daerah-daerah lainnya di tatar Sunda, yaitu ditiup dan dipukul. Orang tua bilang, jika tahu embat 'panjang lurus'nya memainkan karinding, setiap orang pasti bisa. Caranya adalah sebagai berikut: Karinding harus dipegang erat dengan jari tangan sebelah kiri dan ditempelkan di bibir untuk ditiup; sementara itu ujung karinding sebelah kiri dipukul dengan telunjuk, keras dan menggunakan pantulan; kemudian setelah mampu menghasilkan getaran secara intens, dengan ditempelkan di mulut sebagai resonansinya dan lidah sebagai pengontrol bunyi yang kita inginkan, sesekali bagian tengah Karinding disentuh untuk menghasilkan bunyibunyi atau nada-nada tertentu.

Untuk mendapatkan hasil suara/bunyi yang berbeda-beda adalah dengan cara meniupnya dengan mulut kosong tanpa napas dan dengan menggunakan napas. Dengan memainkan lidah dan napas akan menghasilkan suara-suara yang khas, yang berbeda dari tiap orang yang memainkannya. Hal itu karena setiap orang memiliki konstruksi mulut yang berbeda. Kemudian, untuk mendapatkan kualitas suara karinding yang baik atau bagus, adalah: pertama, tentunya alat karindingnya sendiri harus dalam keadaan baik, kering, dan nyaring bunyinya. Kedua, cara memainkannya yang benar serta terampil. Jari telunjuk terampil memukul serta diri terampil mengatur lidah dan napas ketika meniup karinding.

\section{d. Fungsi Karinding}

Telah disebutkan pada sub bab sebelumnya, bahwa fungsi karinding pada masyarakat Desa Cirama Girang pada masa lalu adalah lebih pada fungsi karinding sebagai pemelihara tanaman di 
sawah, yaitu alat pengusir hama. Dimainkan sendiri, kemudian bermusik sendiri, tentunya sekaligus sebagai hiburan untuk menyenang-nyenangkan diri di tengah-tengah waktu bekerja di sawah.

Selanjutnya, karinding menginjak sebagai hiburan untuk orang banyak, tatkala masa panen tiba. Ketika warga disibukkan dengan kegiatan mangkek pare, yaitu mengikat ranggeuyan 'tangkaian' padi yang telah kering di saung 'dangau' menjadi pocongan, saeundan-saeundan 'satu ikat satu ikat'. Padi hasil mangkek, kemudian digedeng jadi sageugeus-sageugeus, yaitu dua eundan diikat jadi satu geugeus. Kegiatan yang biasanya dikerjakan oleh banyak orang atau secara gotong royong ini, tentunya akan lebih bersemangat jika disuguhi hiburan. Karinding pun tampil sebagai alat hiburan yang mudah, murah, namun unik, menarik, dan enak didengar. Karinding pun berfungsi sebagai hiburan untuk menyemangati mereka yang sedang bekerja.

Sebagai alat hiburan, karinding tak hanya berhenti sampai menghibur warga yang bergotong royong ketika panen saja. Karinding pun sering tampil mengisi acara perayaan hari-hari besar, hajatan atau kenduri yang diadakan warga, serta memproklamirkan sebagai bentuk kesenian. Bahkan kerap diibingan 'diiringi tarian' dan nyanyian pesinden.

Kini fungsinya berkembang ke bentuk kesenian, yang tentunya dalam penampilannya tak hanya sekadar tampil, tetapi memperhatikan pula aspek-aspek dasar sebuah pertunjukan. Selain materi pertunjukan dituntut lebih bervariasi, juga kesenian ini dituntut untuk bisa ngigelan 'mengikuti' perkembangan seni kekinian. Materi lebih bervariasi, dalam artian seniman karinding meningkatkan kemampuan bermainnya, dengan menambah jenis dan macam lagu yang dimainkan, misalnya. Hal itu telah dilakukan para seniman karinding Cirama Girang. Mereka menambah jenis serta macam lagunya, tidak hanya kakawihan atau lagu-lagu Sunda lama, juga lagu-lagu baru. Kemudian dalam ngigelan perkembangan seni kekinian, dalam artian mencoba meraih para penikmat seni - penonton - dari berbagai lapisan usia dan kalangan, mereka telah mengkolaborasikan musik karinding dengan alat-alat musik atau waditra lainnya, seperti kacapi, celempung, panambih, dan kecrek dari bambu.

Fungsinya kemudian menjadikan karinding sebuah seni pertunjukan, bagi senimannya selain sebagai upaya pelestarian dan pengembangan warisan leluhur; juga sebagai penghasilan sampingan dalam mata pencaharian utamanya sebagai petani.

\section{Penutup}

Karuhun atau leluhur Sunda merupakan satu rumpun bangsa yang tidak dapat menjauhkan diri dari alam lingkungannya, khususnya dari tumbuhtumbuhan. Sebagai peladang, kemudian berkembang menjadi seorang petani, dalam kesehariannya semakin lekat dengan kehidupan alam. Mereka mengolah sumber daya alam Priangan yang subur untuk kelangsungan hidupnya, dengan tetap memelihara keseimbangan alam dan lingkungannya. Leluhur Sunda menciptakan dan menjaga hubungan harmonis antara manusia dengan alam, sebab mereka menyadari hubungan yang terjadi adalah hubungan yang saling membutuhkan. Prinsipprinsip budaya, termasuk ilmu pengetahuan mereka ternyata memiliki nilainilai kearifan akan hubungan harmonis di atas.

Demikian, dalam menciptakan sesuatu, leluhur Sunda tidak sekadar menciptakan. Contohnya, menciptakan 
suatu alat tidak sekadar menciptakan alat. Namun, di balik itu terkandung nilai-nilai kearifan, yang menyelaraskan hubungan manusia dengan alam lingkungannya. Contohnya karinding. Karinding sebagai alat pengusir hama di sawah yang bebas pestisida, sekaligus sebagai alat musik karena menghasilkan bunyi. Binatang harus hidup untuk keseimbangan alam, sehingga tidak perlu dibunuh. Karinding terbuat dari pelepah aren/kawung atau bambu, yang dibentuk sedemikian rupa sehingga ketika dimainkan/dioperasikan menghasilkan suara dan getaran yang low decible, yang hanya bisa didengar oleh binatang jenis serangga.

Alat karinding yang bisa digunakan untuk bermain musik pun kemudian berkembang menjadi alat musik tradisional Sunda yang mengagumkan. Karinding termasuk alat musik sejenis harpa rahang. Cara menggunakannya, selain ditiup, ujung karinding dipukul dengan telunjuk hingga menghasilkan bunyi. Alat ini ditempatkan di mulut sebagai resonansinya, dan lidah sebagai pengontrol bunyi yang diinginkan.

Hal yang menarik sekaligus unik dari alat musik karinding ini adalah; pertama, dengan cara dipukul mampu menghasilkan bunyi yang variatif cukup banyak; kedua, suara tiap orang yang memainkan akan berbeda dengan yang lainnya - walaupun memainkan rahel 'ketukan waditra' yang sama, karena setiap orang memiliki konstruksi mulut yang berbeda.

Seni tradisi yang cenderung statis, bisa tampil beda jika diolah dengan teknik ungkap baru. Demikian, alat musik karinding pun dikolaborasikan dengan perkakas musik atau waditra Sunda lainnya, bahkan dengan alat musik etnis lainnya. Hasilnya mengejutkan, karinding mampu "berdialog" dengan perangkat musik tersebut dan meng- hasilkan nada yang unik seperti musik dari dunia masa depan.

Masyarakat Cirama Girang di Cikalongkulon, Kabupaten Cianjur adalah salah satu kelompok masyarakat yang masih mengenal alat musik karinding. Fungsi karinding yang semula sebagai alat pengusir hama di sawah, kemudian berperan sebagai alat musik yang dapat menghibur dan menyemangati orang-orang ketika bekerja di sawah; dan akhirnya berkembang menjadi sebuah kesenian, kesenian Karinding. Kesenian Karinding mereka telah mampu berkolaborasi dengan perangkat waditra lain, yaitu celempung, kacapi, panambih, dan kecrek. Tak hanya itu, bahkan dalam penampilannya bisa diibingan dan diiringi nyanyian pesinden. Walau dengan penambahan waditra yang kondisinya sangat sederhana, kesenian Karinding ini mampu tampil mengesankan dalam acara-acara hiburan di daerahnya.

Dengan sarana yang seadanya, para seniman karinding di Cirama Girang ini berupaya kesenian Karinding tetap mendapat tempat di hati para pendukungnya, terutama di daerahnya sendiri. Untuk tampil di luar daerahnya, mereka belum berani. Hal itu terkait dengan kelewat "sederhananya" waditra tambahan yang mereka miliki. Walaupun begitu, berbicara masalah kualitas, suara musik yang dihasilkan tak kalah dengan suara musik yang dihasilkan waditrawaditra berkondisi baik.

Tak dipungkiri para senimannya, kesenian Karinding harus bersaing dengan kesenian modern yang lebih banyak dipilih dan diminati orang. Satu hal yang seharusnya dilakukan agar kesenian Karinding tetap bertahan adalah dengan memberinya "ruang hidup". Caranya adalah dengan memberi kesempatan kepada mereka untuk tampil dalam berbagai kesempatan. Jadi, harus 
ada moment untuk mengapresiasi seni karinding ini, dengan memberi kesempatan kepada senimannya tampil dalam berbagai acara. Dengan demikian, masyarakat akan mulai mengenal seni ini, dan tergugah untuk dapat memainkannya dan mengetahui lebih jauh tentang kesenian ini. Apabila masyarakat memberikan apresiasi atas kesenian ini, hal itu akan memotivasi para pemain/seniman karinding untuk tidak meninggalkan seni tradisional ini.

Selain para penikmat, pemerhati, dan pencinta kesenian tradisional yang diharapkan dapat mewujudkan upaya pelestarian dan pengembangan kesenian Karinding, juga tak kalah pentingnya adalah pemerintahan daerah setempat yang terkait dengan masalah ini, diharapkan dapat memberi "ruang hidup" di dalam dan di luar wilayah pendukungnya. Memberi "ruang hidup", selain memberi kesempatan untuk bisa tampil, juga memfasilitasinya dengan sarana dan prasarana yang baik. Dengan demikian, regenerasi seniman Karinding dapat berjalan mulus, dan upaya pelestarian serta perkembangan kesenian Karinding dapat terwujud, sehingga catatan kekayaan khazanah budaya Sunda di wilayah Jawa Barat tidak sampai memasukkan kesenian Karinding ini dalam kelompok kesenian-kesenian yang nyaris punah, apalagi sudah punah. Jangan pernah.

\section{DAFTAR PUSTAKA}

Andayani, Ria. 2007.

Penolak Bala pada Masyarakat Banceuy: Sawen. Bandung: Departemen Kebudayaan dan Pariwisata, Balai Pelestarian Sejarah dan Nilai Tradisional Bandung.
Atmadibrata, Enoch et al. 2006.

Khazanah Seni Pertunjukan Jawa Barat. Bandung: Dinas Kebudayaan dan Pariwisata Jawa Barat \& Yayasan Kebudayaan Jayaloka.

Ensiklopedi Nasional Indonesia, No. 8. 1990.

Jakarta: Cipta Adi Pustaka.

Garna, Yudistira K. 1996.

Ilmu-ilmu Sosial Dasar - Konsep Posisi. Bandung: Program Pascasarjana Unpad.

Iskandar, Johan. 1992.

Ekologi Perladangan di Indonesia. Studi Kasus dari Daerah Baduy, Banten Selatan, Jawa Barat. Jakarta: Djambatan.

Koentjaraningrat. 1961.

Pengantar Antropologi. II. Jakarta: Rinda Cipta.

Rohidi, Tjetjep Rohendi. 2000.

Ekspresi Seni Orang Miskin: Adaptasi Simbolik terhadap Kemiskinan. Bandung: Nuansa.

Rosidi, Ajip et al. 2000.

Ensiklopedi Sunda. Alam, Manusia, dan Budaya - Termasuk Budaya Cirebon dan Betawi. Jakarta: Pustaka Jaya.

Rusnandar, Nandang. 2003.

"Awi" dalam Kehidupan Sosial Budaya Masyarakat Sunda. Bandung: Departemen Kebudayaan dan Pariwisata, Balai Pelestarian Sejarah dan Nilai Tradisional Bandung.

Scott, James C. 1993.

Perlawanan Kaum Tani. Jakarta: Yayasan Obor Indonesia.

Sopandi, Atik et al. 1985/1986.

Peralatan Hiburan dan Kesenian Tradisional di Jawa Barat. 
Jakarta: Depdikbud Dirjen Kebudayaan, Direktorat Sejarah dan Nilai Tradisional, Proyek Inventarisasi dan Dokumentasi Kebudayaan Daerah.

\section{Majalah dan Surat Kabar:}

Majalah Analisis Kabudayaan. 1981/1982.

Retno HY. 2008.

"Identitas Sunda dalam Musik Bambu". Pikiran Rakyat, 13 Oktober 2008.

Wulandari, Catur Ratna. 2008.

"Potensial Secara Ekonomi dan Bisa Dikembangkan Belum Tersentuh Konservasi”. Pikiran Rakyat, 26 November 2008.
2008.

"Berguru pada Rumpun Bambu" Pikiran Rakyat, 26 November 2008.

\section{Sumber Elektronik:}

Bunyi Karinding yang "Futuristik". Dudi RS/Priangan. Kamis, 29 Agustus 2002. http: //www.pikiranrakyat.com/cetak/0802/29/khazana h/lain 05.htm.

Mengungkapkan Cinta Lewat "Karinding". Undang Sudrajat. Kamis, 03 Mei 2007. http: //www.pikiran-rakyat.com/cetak/ 2007/052607/03/0105.htm.

Karinding Nyaris Terlupakan. Senin, 14 Mei 2007. http: //www.kompas. com/kompas-cetak/0705/14/jabar/ 21940.htm. 